I. С. Матвієнко, кандидат філософських наук, асистент кафедри філософії НУБІП України

\title{
АВТОР, ТЕКСТ, ДИСКУРС: ФІЛОСОФСЬКІ РОЗВІДКИ МІШЕЛЯ ФУКО
}

3 часів, коли виникла писемність, виникла і проблема автора, адже автор як просвітник несе світло смислу у своїх творах, де смисл самої праці зводиться винятково до задуму автора, хоча кожен текст може мати набагато глибший зміст, ніж вкладає в нього автор. Саме тому проблема автора і тексту, їх взаємодії є вельми актуальною. Текст не завжди вміщає в себе лише той смисл, який вклав у нього автор. Звичайно, можна говорити про «вузьке читання», а також про «уважне читання» та містифікацію автора як творця. Саме тому розщеплення функцій автора в мові на сьогодні досить реальне. Філософська система Мішеля Фуко змінює наше ставлення до тексту та автора, до їх взаємодії. І для М.Фуко, і для Р.Барта проблема визначення та ролі автора тексту перебуває під питанням. Запозичивши у Ролана Барта історичний підхід до поняття «автор», Мішель Фуко визначає його через поняття «індивідуалізація».

Починаючи з Античності поняття «автор» означало внесення свого імені до історії. До XVIII ст. термін «автор» визначався більше як «власник» тієї чи іншої праці, а не як людина, яка їі написала. Саме тому Фуко звертає увагу на те, що через дослідження тексту можна пізнати автора, а не навпаки.

Проблема взаємовідносин між автором та текстом і питання зникнення автора постала ще на початку XX ст., але свого розвитку набула в середині XX ст., коли з'являються французькі структуралісти: Р.Барт, Ю.Крістєва та М.Фуко. Але ми спинимося на праці М.Фуко «Що таке автор?» (1969р.). Дослідження філософської спадщини французького мислителя є вельми актуальним сьогодні, адже проблеми, які він піднімає, були актуальні в середині XX ст. та актуальні і сьогодні. Досить детальний огляд проблеми взаємодії автора та тексту можна знайти у працях П. де Мана, С.Бьорка, М. Фрайзе, І.Ільїна, Б.Кормана, А. Большакова та ін. Основною метою статті є розкриття понять «автор», «текст», «дискурс» та їх 
взаємодія, які представлені у філософській спадщині М. Фуко.

Мішель Фуко висунув оригінальну концепцію європейської культури, в якій не останнє місце посідають такі поняття, як «дискурс», «епістема», «мова», «твір» та «автор». Коли ми говоримо про іменитих авторів чи їх роботи, ми можемо визначати певні їх особливості чи характеристики того чи іншого автора, але як визначити саме поняття «автор»? В академічному тлумачному словнику української мови слово «автор» означає: «чол. Той, хто написав будь-яку працю, твір, лист і т. ін. або розробив якийсь план, проект і т. ін.» $[3,13]$. Ми всі можемо якимось чином визначати це поняття, тобто автор - це той, хто щось створює, хто винаходить щось нове, але у літературі та філософії автором є не кожен. Для М. Фуко автор - це і людина, але його цікавить питання з приводу «правил, за якими вони визначили певну кількість понять чи теоретичних ансамблей, які можна віднайти в їх текстах» [4], за якими ми говоримо, що це дійсно автор цього тексту. Адже автори можуть бути різні, і абсолютно в різних сферах життєдіяльності - в біології, фізиці, літературі, поезії. І чи однаковими є поняття автора в фізиці та поезії та за якими критеріями їх можна визначити. Отже, на думку М.Фуко: «це поняття автора конституює важливий момент індивідуалізації в історії ідей, знання, літератур, так само як і у філософії, і науці» [4].

М.Фуко не займається історико-соціологічним аналізом персонажа автора, він не зацікавлений у відносинах та переживаннях автора, коли він починає передавати свої власні відчуття, а не фантазію або вигадку. Його цікавить лише ставлення «твору до автора». Найголовнішим лозунгом цього ставлення М. Фуко визначає для себе слова Семюеля Беккета: «Яка різниця, хто говорить, - сказав хтось, яка різниця, хто говорить» [4], цей вислів, і є фундаментальним етичним принципом сучасного письма. Адже для людини XXI ст. не має різниці, хто написав працю, головне, який вона має смисл. А чи завжди смисл твору визначається лише автором, який iï написав? Чи, можливо, кожен читач вносить щось своє?

На сьогодні будь-яка робота приймається, як така, яка є сама по собі, а не така, яка розглядається з точки зору їх взаємодії, тобто праця, яка $є$ написаною, уявляється нам як «гра знаків». Запис розгортається, як гра, яка незмінно виходить за межі своїх власних правил. Тобто в межах якоїсь праці виникає певний простір, в якому зникає суб'єкт як такий. Таким чином, коли ми робимо запис, 
ми скасовуємо певні ознаки індивідуальності. Так що знаки, в яких виражається твір, певним чином «вбиває автора». Тобто, письменник відіграє роль «померлої особи», що бере участь у грі письма. Саме тому М.Фуко доходить висновку, що автор зникає, але при цьому говорить, і що виняток з правил, коли ми говоримо про ідеологічні конструкції, до яких він відносить таких представників, як Карл Маркс, Зігмунд Фройд та ін., це ті автори, яких створив жанр та породив писати в конкретній галузі. Але це скоріше виняток 3 правил, ніж правило.

Автор для М.Фуко - скоріше функціональний принцип, за допомогою якого обираються та виключаються певні роботи. Автор на сьогодні виконує функцію, яка вже знищена в науці, адже коли ми говоримо про істину, то чи можемо ми говорити про автора icтини? Це питання в літературі теж є досить актуальним, ми вже не говоримо про автора тексту, а говоримо про популярність в продажу тієї чи іншої книги. Фуко закликає не цементувати ідею «автора» як певного власника ідеї, але дестабілізувати ідею створення обмежень і обмеженого поля, бо в усіх випадках, дискурс перевищив письменників, як це було у марксизмі та фройдизмі.

Коли йдеться про від'єднання автора від його праці, ми можемо стверджувати, що література, таким чином, зміщується у бік дискурсу. Тому у праці Р.Барта «Смерть автора» (1968 р.) спостерігається тенденція актуалізувати читача. Для М.Фуко ж у праці «Що таке автор?» (1969р.) автор, ніби залучений в системі мислення, яка проявляє себе через персоніфікацію, що постала на шляху кращого об'єкта дослідження - дискурсу.

Для праць пізнього Фуко пріоритетним є поняття «дискурс», яке посідає центральне місце, але як можна його визначити: «створену за допомогою тексту картину реальності; велику смислову структуру, яка має тематичне ядро; репрезентацію власних відношень і ідеологічних установок, які визначають певну програму дій; комунікативнознакову систему в єдності ії інтерпретації (програмної установки), актуалізації (втілення) та контексту»? [2, 6]. Як зазначає Е.Кротков, дискурс - це мовно-мисленнєва діяльність, яку регламентують соціокультурні коди, такі, як цінності, традиції, певні правила, які були визначені суспільством, та за допомогою яких людство виробляє та трансформує знання та моделі соціального досвіду. Дискурс постає як певний мовний феномен, який функціонує за допомогою мовних (граматичних) правил, але використання дискурсу враховує i 
соціальні особливості, і цілі учасників комунікативного дискурсу. Саме завдяки дискурсу можна провести тонку лінію між матеріальним світом та мисленням, між свідомістю та поведінкою.

Дискурс являє собою знакову систему, певну послідовність літер, слів та висловів. Це, так би мовити, певний текст, створений автором, але здатний вести абсолютно автономне існування, не маючи ніякого зв'язку з власним автором. Але, з іншого боку, як зазначають І.Б.Костіна, А.Б.Костін: «...Тематичне ядро дискурсу, його смислова структура незмінно стимулюють цільову інтенцію дискурсу - те внутрішнє зусилля, яке іде від суб'єкта (автора або читача), завдяки якому дискурс включається в соціальні відношення, стає подією і співвідноситься 3 іншими дискурсами» [1, 108]. М.Фуко розглядає поняття дискурсу подвійно: $з$ одного боку, він такий, що має об'єктивну текстову форму, яка існує незалежно від будь-якого суб'єкта, а з іншого, - містить в собі власну незалежну смислову структуру, яка все ж таки була створена автором і яка визначає собою характер зв'язків між елементами цього дискурсу.

Отже, відомий французький мислитель Мішель Фуко, аналізуючи проблему взаємовідносин між текстом та автором, розглядає автора як певну функцію, яка є проявом у вигляді категорії суб'єкта та залежить від умов, в яких існує та проявляє себе дискурс в конкретних історичних та просторових межах певної визначеної історично культури.

\section{ЛІТЕРАТУРА}

1. Костина И.Б., Костин А.Б. Имя автора, историчность и дискурсивные практики в археологи знания М. Фуко / Исторические, философские, политические и юридические науки, культурология и искусствоведение. Вопросы теории и практики. - Тамбов: Грамота. - 2013. - № 4 (300) : в 3-х ч. Ч. І. - С.107-110.

2. Кротков Е.А. Дискурсная модель научной рациональности. - Белгород, 2009. - $164 \mathrm{c}$.

3. Словник української мови: в 11 томах. - Том 1. - 1970 // Режим доступу: http://sum.in.ua/s/avtor

4. Фуко $M$. Что такое автор // Фуко $M$. Воля к истине: по ту сторону знания, власти и сексуальности. Работы разных лет. - М., 1996. - 448 с. // Режим доступу: http://lib.ru/ COPYRIGHT/ fuko.txt 
Матвієнко I.С. Автор, текст, дискурс: філософські розвідки Мішеля Фуко.

В статті аналізуються філософські ідеї М. Фуко, який надає особливого смислу поняттям «автор», «текст» та «дискурс». Оригінальна система Мішеля Фуко змінює наше ставлення до тексту, автора та їх взаємодій. Будь-який текст виявляється в певних мовних знаках, а коли вже відбувся момент виразу, текст починає своє власне існування, незалежно від автора, адже кожен читач надає цьому тексту власний унікальний смисл. I тільки завдяки дискурсу можна знайти точки дотику між автором, твором та читачем. Автор причетний до системи мислення, яка проявляє себе через персоніфікацію, що постала на шляху кращого об'єкта дослідження: дискурсу. Дискурс є певним мовним феноменом, який функціонує за допомогою мовних (граматичних) правил, але дискурс має i соціальні особливості, і цілі учасників його.

Ключові слова: автор, текст, суб’єкт, дискурс, культура.

Матвиенко И. Автор, текст, дискурс: философские исследования Мишеля Фуко.

В статье анализируются философские идеи М. Фуко, который придает особый смысл понятиям «автор», «текст» и «дискурс». Оригинальная система Мишеля Фуко меняет наше отношение к тексту и автору, и их взаимодействию. Любой текст выражается в определенных языковых знаках, а когда уже произошел момент выражения, то текст начинает свое собственное существование независимо от автора, ведь каждый читатель придает этому тексту собственный уникальный смысл. И только благодаря дискурсу можно найти точки соприкосновения между автором, произведением и читателем. Автор причастен к системе мышления, которая проявляет себя через персонификацию, что встала на пути лучшего объекта исследования: дискурса. Дискурс предстает как определенный языковой феномен, который функционирует при помощи языковых (грамматических) правил, но дискурс имеет и социальные особенности, и цели участников.

Ключевые слова: автор, текст, субъект, дискурс, культура.

Matviienko I. Author, text and discourse: philosophical studies of Michel Foucault.

The article presents an analysis of the philosophical ideas of Michel Foucault, which gives special meaning to the concept of «author», «text» and «discourse». The splitting of the functions of the author in the language today is very real. The original system of Michel Foucault changes our relationship to the text and author, and their interactions. Any text expressed in the specific 
language signs, and when it occurred the expression, the text begins its own existence regardless of the author, who wrote it, because each reader gives the text its own unique meaning, and only through discourse we can find common ground between author, work and reader. The author, though involved in the system of thinking which manifests itself through personification that stood in the way of the best of the object of discourse analysis. The discourse appears as a particular linguistic phenomenon, which functions by means of language (grammatical) rules, but the use of discourse takes into account social characteristics, and purposes of parties to a communicative discourse.

Key words: author, text, subject, discourse, culture 